\title{
Multicriteria GIS-Based Approach in Priority Areas Analysis for Sustainable Urban Drainage Practices: A Case Study of Pato Branco, Brazil
}

\author{
Claudinei Rodrigues de Aguiar ${ }^{1,2, * \mathbb{C}}$, Jéssica Klemm Nuernberg ${ }^{2}$ and Thays Cristiane Leonardi ${ }^{2}$ \\ 1 Department of Civil Engineering, Federal University of Technology_Paraná, \\ Apucarana 86812-460, Paraná, Brazil \\ 2 Civil Engineering Postgraduate Program, Federal University of Technology—Paraná, \\ Pato Branco 85503-390, Paraná, Brazil; jessica_kn@hotmail.com (J.K.N.); thaysleonardi@gmail.com (T.C.L.) \\ * Correspondence: rodriguesaguiar@utfpr.edu.br; Tel.: +55-043-3162-1200
}

Received: 3 September 2020; Accepted: 25 September 2020; Published: 28 September 2020

\begin{abstract}
Geographic information systems (GIS) and multicriteria decision methods are robust techniques for supporting the urban planning process, including urban drainage. New low-impact management approaches (LID) for rainwater have been investigated and have become increasingly used. Considering the central region of Pato Branco city, which suffers recurrent problems related to flooding, this work presents a method to identify potential areas for the application of LIDs, such as rainwater collection tanks, permeable pavements, green roofs, and rain gardens. The identification of these areas is based on the analysis in a GIS environment considering criteria related to both the land slope, the characteristics of land use and technical parameters. Thus, we observe that rainwater collection tanks are indicated for all habitations, permeable pavements are recommended for $6.30 \%$ of the study area, while green roofs can be implemented in 3.97\% of the area. Finally, $3.03 \%$ can receive rain gardens. In total, $13.30 \%$ of the central region of Pato Branco can receive LIDs. The results obtained reveal that the use of the GIS tool associated with multicriteria analysis is efficient in choosing locations for the implementation of LIDs as alternatives for the management of urban drainage.
\end{abstract}

Keywords: geographic information system; multicriteria analysis; urban drainage; LID

\section{Introduction}

The urbanization process impacts on the urban environment and has caused recurrent damages and losses to the population. Among the main problems are the changes in land use [1], waterproofing of the soil surface [2], floods [3], and changes in the urban hydrological cycle [4]. Consequently, these impacts increase the volume of runoff [5], changing the quality of the water that drains superficially [6] and the decrease in underground recharge [7].

Floods are worrisome because approximately $80 \%$ of the world population [8] is subject to financial damage, destruction of infrastructure, and deaths due to this phenomenon $[9,10]$. In addition, the socioeconomic risks associated with floods are more evident when the phenomenon occurs in an urban area compared to rural areas [11], these risks have led to a diversity of studies on the causes of floods $[10,12,13]$.

Climate change can increase both frequency and magnitude of floods on a global scale [14]. The increase in emissions of gases that contribute to the greenhouse effect can contribute to reducing the period of return of extreme precipitation, making flash floods more frequent [15,16].

Besides, the physical factors that are generally linked to the occurrence of floods are the gradient of the hydrographic basin, the use and cover of the soil, the permeability of the soil, and the physical 
vulnerability associated with this phenomenon [17]. In the urban environment, floods can also be recurrent due to steep slopes, surfaces impervious to urbanization, and failures in urban drainage [18].

In this sense, traditional urban drainage has been shown to be insufficient and inadequate $[19,20]$, and, therefore, new approaches have been studied to assist in flood mitigation [21]. However, there are still uncertainties in the scientific community about the advantages of sustainable drainage systems over traditional systems [22,23].

In urbanized areas, allocating land for major urban drainage works, such as detention basins, galleries, and infiltration basins, may not be a viable option. Thus, a strategy is to use retrofit techniques for the existing infrastructure, restoring river basins, and providing rainwater treatment in places where the practices previously did not exist or were ineffective [24]. Retrofit techniques can be applied to built-up areas, such as parking lots, sidewalks, and roofs.

In this context, the Low Impact Development (LID) emerges as a proposal for sustainable urban drainage practice in order to aim for solutions for the management of rainwater $[25,26]$. Examples of LID typologies include green roofs, rain gardens, bio-retention cells, ditches, permeable pavements, infiltration basins, infiltration ditches, rain cisterns, among other devices [27]. These systems seek to mitigate the effects of urbanization by reducing runoff and increasing infiltration, thus creating permeable and rainwater retention areas [28,29].

As a device option to aid urban drainage, permeable pavements promote infiltration and, consequently, reduce runoff [30] and peak flow [31]. Brown [32] indicates the use of permeable pavements in parking lots and streets with flowing traffic, such as in residential condominiums and sidewalks. For Beaupre et al. [33], the permeable pavement should be used in relatively flat locations to facilitate infiltration and minimize erosion, with a maximum slope of $5 \%$ for porous asphalt, $10 \%$ for permeable concrete, and $12 \%$ for permeable paving.

Rain gardens are vegetated depressions that can collect water from the surrounding impermeable surfaces, promoting infiltration and evapotranspiration [34]. Ávila et al. [35] indicate that rain gardens are used in soils with medium to high infiltration rates and slopes less than $12 \%$. Christman et al. [36] recommend that rain gardens are indicated for open spaces, with areas from 10 to $1000 \mathrm{~m}^{2}$.

Green roofs help to reduce the speed of rainwater runoff, creating temporary storage and promoting evapotranspiration [36,37]. For Ávila et al. [35], the factor that limits the use of green roofs is the type of roofing in buildings, being recommended for slab roofs. The slope of the slab roof is also a limiting factor, with slopes lower than $20^{\circ}$ (5 in 12 inclination) [33].

The rainwater harvesting (RWH) serves to collect rainwater runoff from roofs and other impermeable areas for non-potable use, such as flushing toilets, washing machines, car-washing, and irrigation [38]. The use of RWH is the simplest of methods and adaptable for the most diverse constructions, as long as it is possible to build a separate pipeline for non-potable water and, as a limitation, the need for continuous monitoring after its construction [33]. Ávila et al. [35] studied the implementation of LIDs in 10 urbanized hydrographic basins, using three sizes of tanks, according to the housing areas. In Japan, small RWH installations are common in individual residences [39].

The Geographic Information Systems (GIS) applied in this scenario represents a support tool in the process of sustainable urban planning. In recent years, some studies have been carried out in this direction, for example, that of Risti et al. [40], who proposed a model to assess the suitability of the soil for sustainable construction in an area of environmental protection. Christman et al. [36], besides the analysis for the implementation of sustainable drainage systems, prioritized the areas that would receive green infrastructure through social criteria.

Shariat et al. [41] used Multicriteria Decision Making (MCDM), GIS and fuzzy set theory to consider flood risk criteria. When applying it to a case study in Tehran (Iran), they obtained risk maps indicating a high or very high flood risk for $10.5 \%$ to $26 \%$ of the total length of the stormwater channels in the study area. Inamdar et al. [42] evaluated the analysis of the multicriteria decision for the proper selection of rainwater catchment sites (SWH), based on economic, social, and environmental objectives. Ariza et al. [43] developed a methodology for the analysis of environmental, social, and economic 
aspects of the implementation of sustainable drainage systems in consolidated urban areas. The authors performed a multiscale analysis, that is, at the city, local and microscale levels.

Thus, given the problems related to recurrent flooding in urbanized areas, this work aims to identify potential areas for the application of LIDs, using the central region of the Pato Branco city as a study area. We use a methodology using GIS-based multicriteria analysis for the integration of geospatial data and technical parameters. To enable data integration, the data were normalized by fuzzy logic. The exclusion of inappropriate areas was applied using Boolean logic in map algebra. The sustainable urban drainage practices chosen (permeable pavement, green roof, rain garden, and RHW) were chosen due to easy implementation in areas with consolidated urbanization. The identification was performed using GIS combined with the analysis of the slope and the characteristics of land use.

\section{Materials and Methods}

In this work, we investigate a method for selection of areas with the potential for an application of four types of LID: 1. rain gardens, 2. permeable pavements, 3. rainwater harvesting, and 4. green roofs. We have opted for these LIDs because of the ease of implementation in areas with consolidated urbanization, with retrofit capacity in a wide range of land use configurations [24,44,45]. In addition, they are sustainable practices, common for rainwater management, with benefits in reducing flow volumes and peak hydrograph [46-49]. The method workflow is represented in Figure 1.

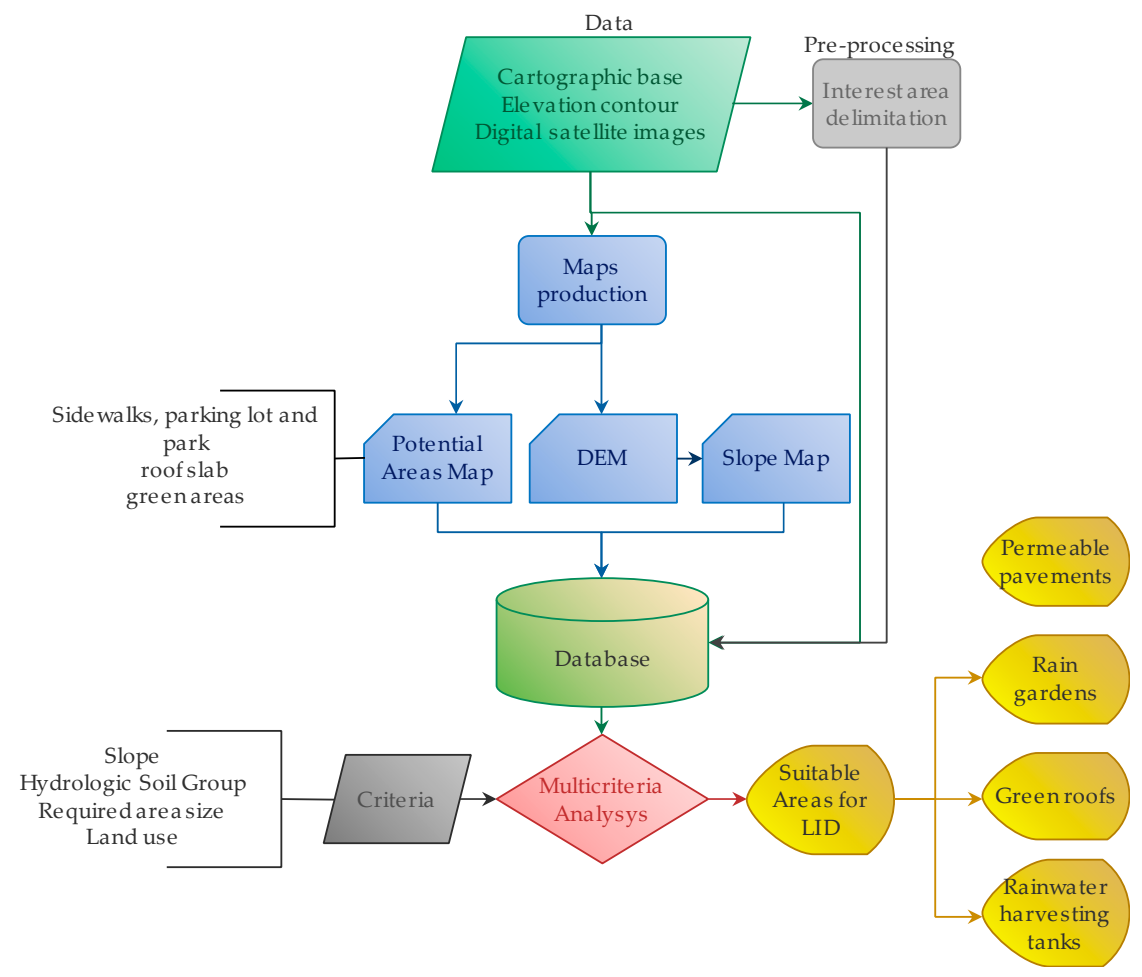

Figure 1. Methodology flowchart.

\subsection{Study Area}

The study area comprises the central urban area of Pato Branco city (Figure 2). Pato Branco is located at coordinates $52^{\circ} 43^{\prime} \mathrm{S}$ and $52^{\circ} 37^{\prime} \mathrm{W}$ in Paraná State, Brazil's south region. The total geographical area is $539,029 \mathrm{~km}^{2}$. The central urban area was chosen because that region is susceptible to recurrent flooding and it is a place with high traffic of people and economic, commercial, and residential interest. 


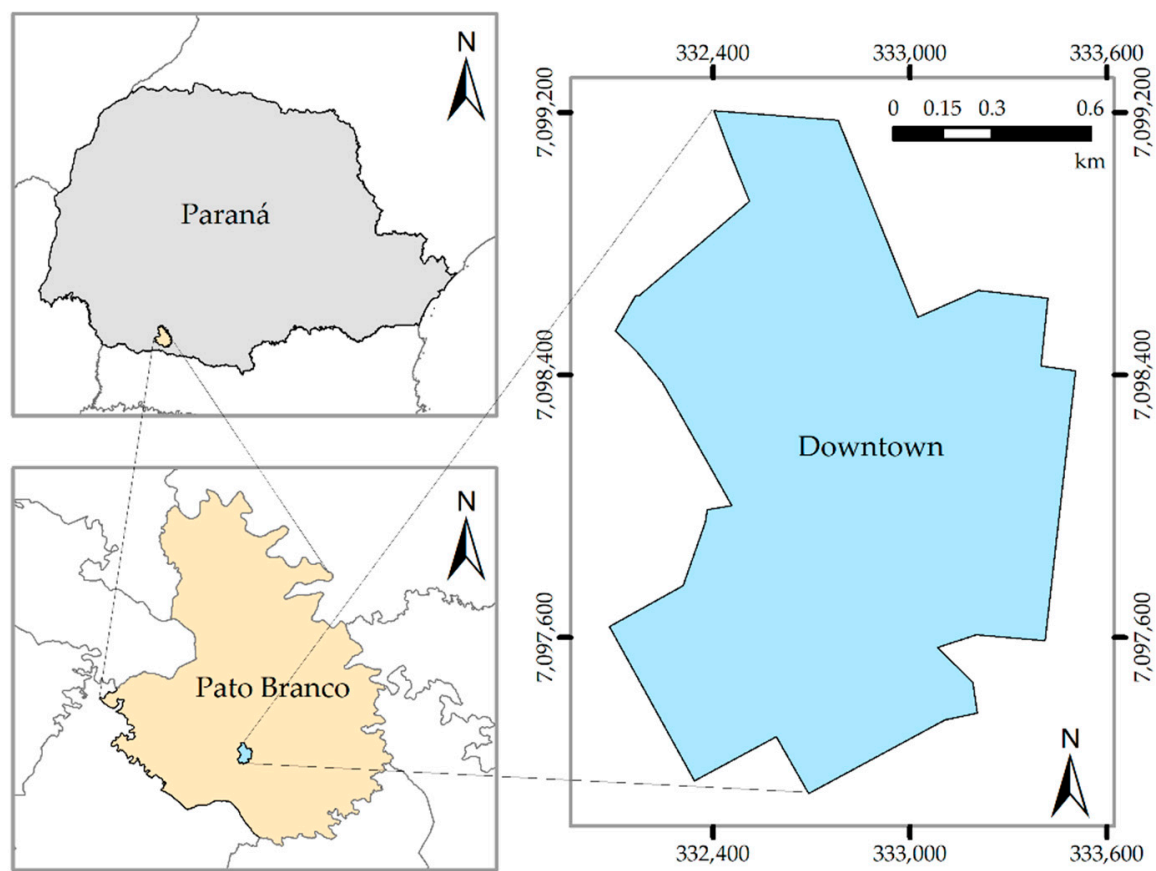

Figure 2. Location map of the study area.

According to the Brazilian Institute of Geography and Statistics (IBGE), Pato Branco has an estimated population of 82,881 inhabitants in 2019 [50], with $94.09 \%$ residing in the urban area and $5.91 \%$ in the rural area. Therefore, the municipality has an approximate demographic density of 134.25 inhabitants $/ \mathrm{km}^{2}$. This region has a temperate climate of the $\mathrm{Cfb}$ type, with well-distributed rains throughout the year. According to the database of the Instituto de Águas do Paraná (Paraná Water Institute), Pato Branco has an average annual rainfall of $2089 \mathrm{~mm}$ (considering 30 years of historical data).

\subsection{Identification of Potential Areas}

The methodology proposed here is based on the multicriteria analysis in a Geographic Information System (GIS) environment. For this, the ArcGIS 10 software was used. In the GIS environment, all the necessary information was organized in layers, sharing a single database. To ensure geospatial compatibility, all information layers were spatially referenced according to the Brazilian Geodetic System, which adopts the Reference System for the Americas-2000 (SIRGAS 2000).

The slope map (Figure 3b) of the study area was generated from the elevation contour every $5 \mathrm{~m}$. In this step, the Digital Elevation Model (DEM) (Figure 3a) was generated from the interpolation by the topo to raster method (ANUDEM) [51]. ANUDEM is a method of morphological interpolation from scattered surface elevation points, elevation contours, streamlines, and others. This model is considered as hydrologically correct to produce DEMs [52,53]. Thus, the slope raster is calculated from the maximum rate in elevation over distance, considering the DEM cell and its eight neighbors. The slope value is calculated by applying the average maximum technique [54].

To obtain the updated cartographic base of the study area, we used multispectral images from the WorldView satellite with a spatial resolution of $50 \mathrm{~cm}$. In this step, the images were vectorized to extract the features of interest according to each LID model. Sidewalks, parking, and squares have been identified as potential areas for permeable pavements. Buildings with slabs were identified for the implementation of green roofs. Finally, parks and areas with vegetation are of interest for the installation of rain gardens. 


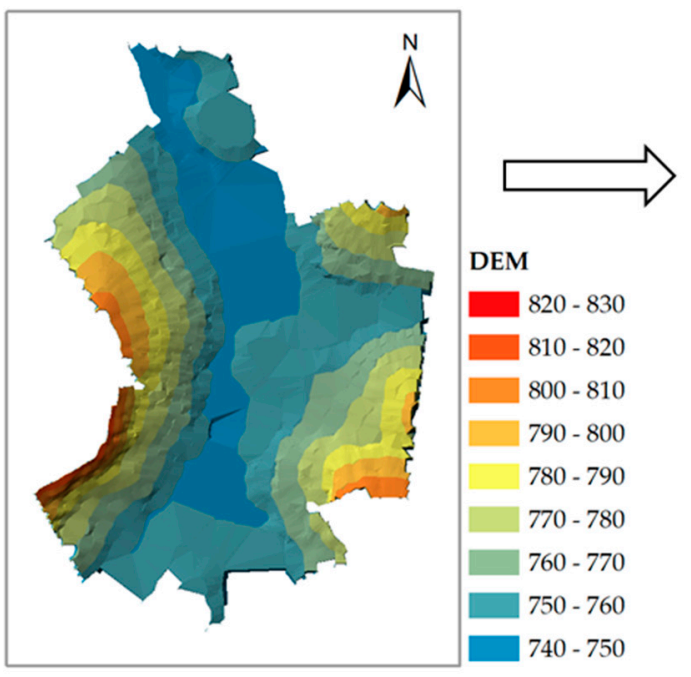

(a)

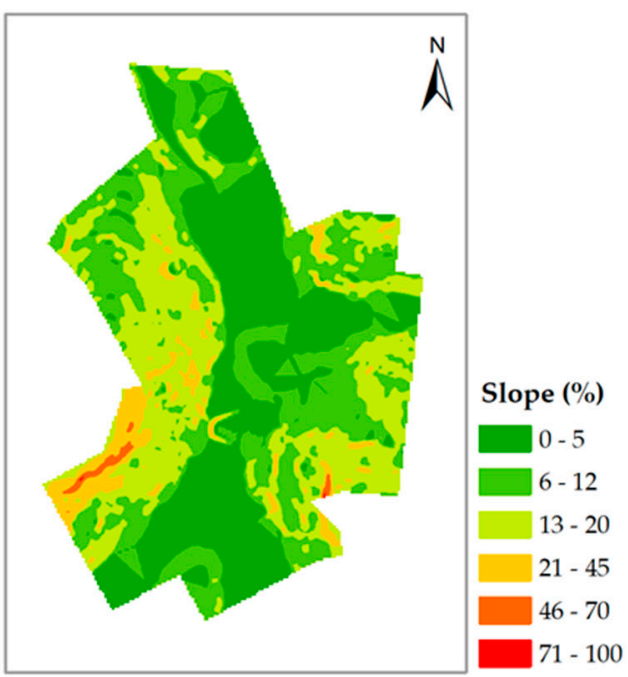

(b)

Figure 3. Digital surface model for the study area. (a) DEM produced by applying the ANUDEM method, (b) slope map generated from the DEM using the average maximum technique.

\subsection{Identification of Conditions for the Implementation of LIDs}

The constraints related to the implantation of LIDs in urban areas were defined according to the data observed in the literature $[33,35,38,55-57]$ (Table 1). In the table, the "required area size" indicates the criteria for implementing the LID in terms of the required area extension. Slope restrictions are established by design criteria, where low slope areas will ensure lower investment costs for surface modification, higher natural storage capacities, and longer infiltration times due to low flow velocities compared to the high slope areas [58]. Land use refers to the type of cover to which each LID is associated.

Table 1. Conditions for the implementation of LIDs.

\begin{tabular}{ccccc}
\hline & $\begin{array}{c}\text { Permeable } \\
\text { Pavement }\end{array}$ & Rain Garden & Green Roof & $\begin{array}{c}\text { Rainwater } \\
\text { Harvesting Tanks }\end{array}$ \\
\hline Slope & $<5 \%$ & $<12 \%$ & $<42 \%$ (roof) & Not applicable \\
Hydrologic Soil Group & $\mathrm{A}-\mathrm{B}$ & $\mathrm{A}-\mathrm{D}$ & Not applicable & Not applicable \\
Required area size $\left(\mathrm{m}^{2}\right)$ & $<12,000$ & $10-1000$ & Not applicable & Not applicable \\
Land use & Paved area & Vegetation area & Roof slab & Not applicable \\
\hline
\end{tabular}

Source: $[33,35,38,59-61]$.

\subsection{Multicriteria Analysis}

After the identification of the areas that meet the requirements for LIDs implementation, we proceeded with the exclusion of areas that were not following the adopted premises (Table 1). For this, it was applied to the map algebra between the map of the possible place of LIDs application and the restrictions maps to verify the areas where the LID can be applied.

Thus, the areas suitable for the permeable pavements consist of sidewalks, parking lots, and squares with a slope of less than $5 \%$. For rain garden adoption, we selected parks and areas with vegetation and slope of less than $12 \%$. Regarding green roofs, the only limiting factor for their use is the type of roof, which must be of the flat slab type.

In this work, we have integrated all information levels based on the GIS environment. Thus, the geospatial data and technical criteria have been normalized using the fuzzy technique, as described in [59]. Fuzzy logic has been extensively applied in various studies, primarily in the treatment of spatial data and real-world representation [58,60-62]. Areas unsuitable for the installation 
of the LID were excluded by applying Boolean logic. The Boolean model involves a logical combination of binary maps using conditional operators of type A AND B (returns the intersection A $\cap$ B), A NOT B (returns the elements contained only in A), A OR B (returns the elements of A and B except those at the intersection $A \cap B$ ). The result is expressed in binary form, 0 for not satisfied, and 1 for satisfied.

\subsection{Flood Susceptibility Map}

To contextualize the potential areas for the implementation of LIDs concerning the occurrence of floods or critical areas for runoff, we also generated the map of susceptibility to flooding events. The overall workflow for this analysis is represented in Figure 4.

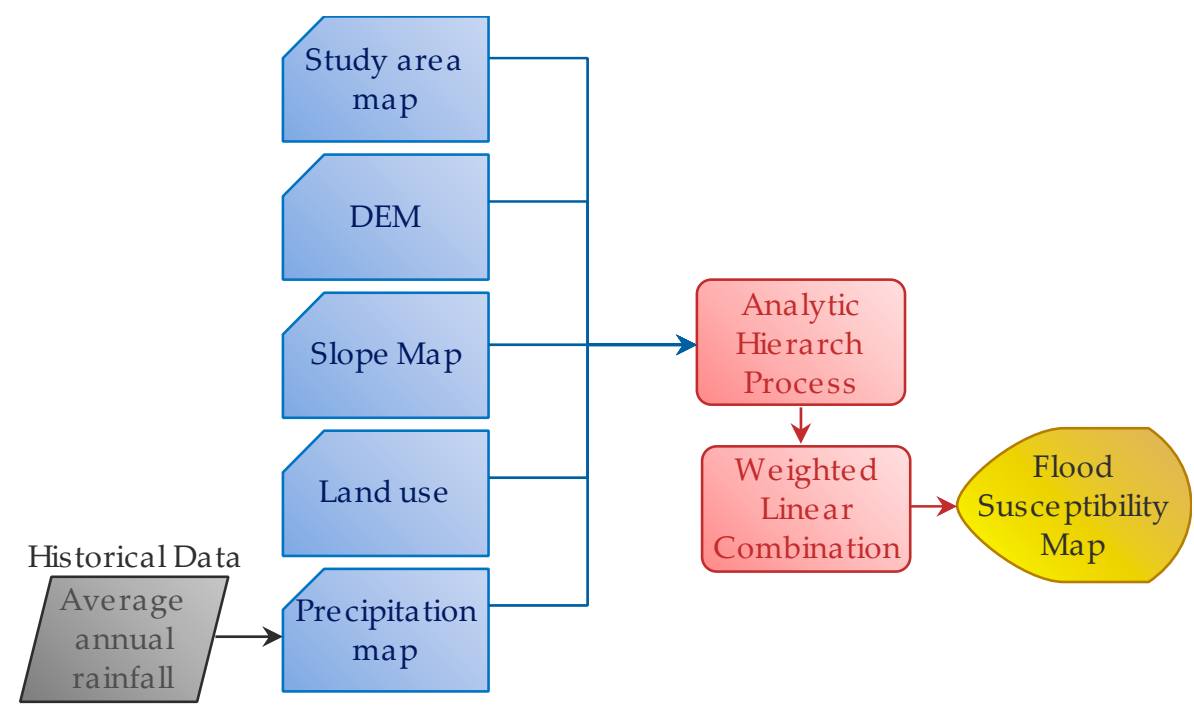

Figure 4. Flowchart for flood susceptibility map generation.

In this case, for the multicriteria analysis, the AHP process was used [63]. The AHP technique is a compensatory mathematical model [64], which was used to define the weights of the criteria. Once weights were defined, the flood susceptibility map was generated from map algebra using a weighted linear combination (WLC). Thus, the map algebra to generate the flood susceptibility map (FSM) was applied according to Equation (1):

$$
\mathrm{FSM}=0.09 \times \mathrm{DEM}+0.18 \times \text { Slope }+0.20 \times \text { Land Use }+0.53 \times \text { Precipitation }
$$

\section{Results and Discussion}

Initially, to identify the areas with potential for the use of LID in the central area of Pato Branco, land use was observed and related to the selection criteria for each model (Figures 5-7). Thus, note that the area for permeable pavements is larger in relation to the others, followed by the rain garden and, finally, the green roof.

The predominance of areas for permeable sidewalks and rain gardens is explained by the prevalence of parking lots, sidewalks, parks, and vacant lots in the area. Thus, it is interesting that these systems are adopted if there is any further modification in the areas that can be built on.

Melville-Shreeve et al. [65], who was interested in understanding the use of LID in the United Kingdom, also identified the wide use of permeable pavement concerning other models. The authors identified that one of the reasons for the results is the fact that in this system, water can be stored or, still, be used as a way of improving water quality. Besides, Jato-Espino et al. [66] also comment in their study that permeable pavements are the easiest systems to implement in a consolidated urban area, due to their multifunctionality, since they act in the infiltration and storage of rainwater and allow the control of runoff. 


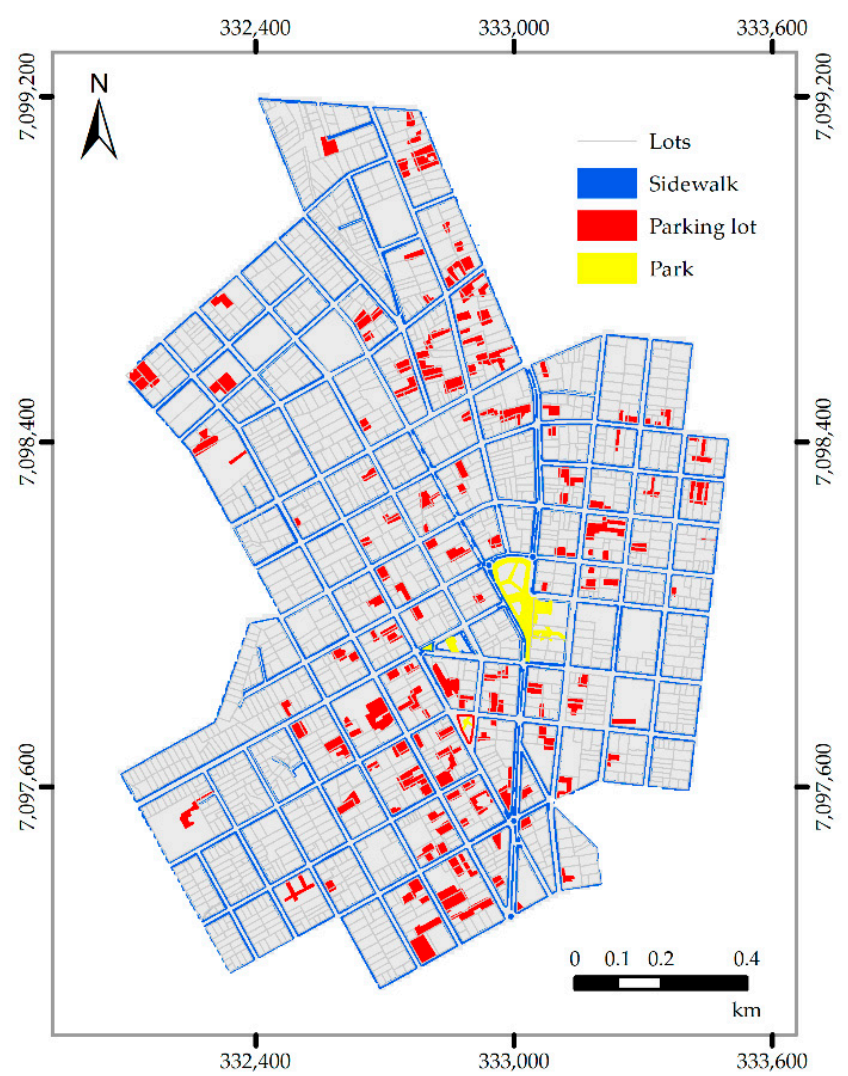

Figure 5. Areas identified by land use to receive permeable pavements.

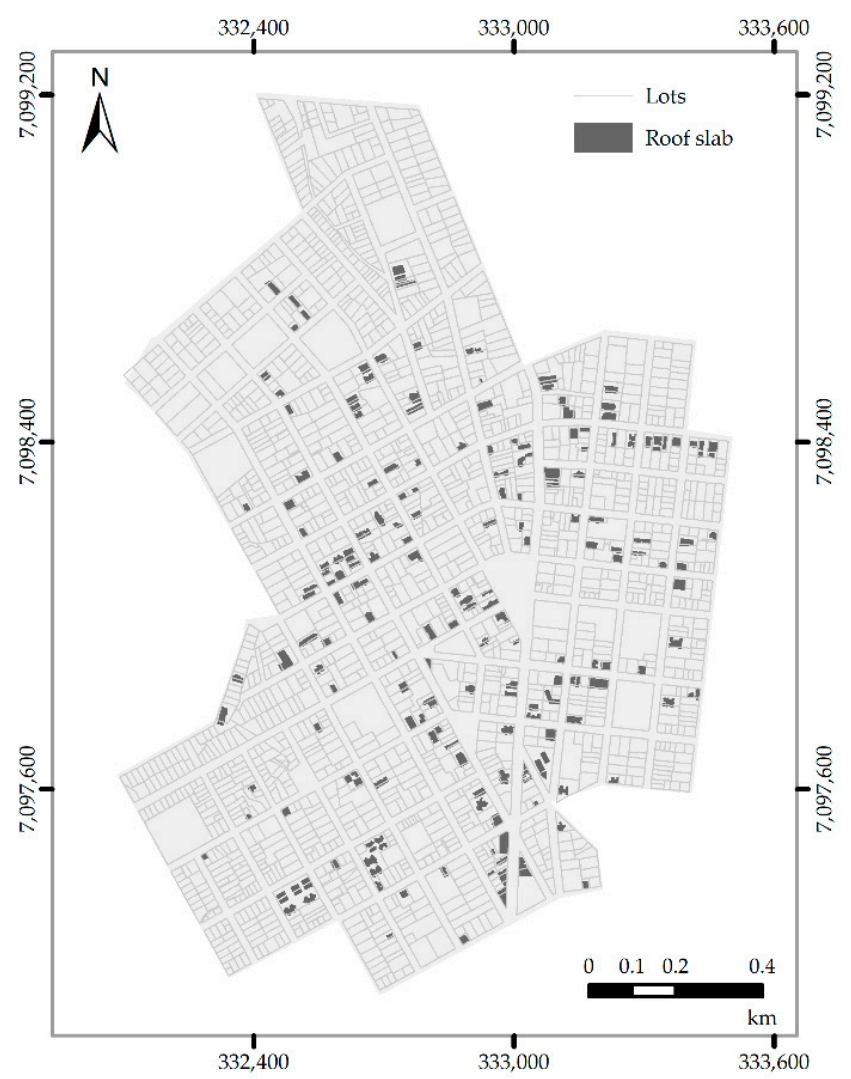

Figure 6. Areas identified by land use to receive green roofs. 


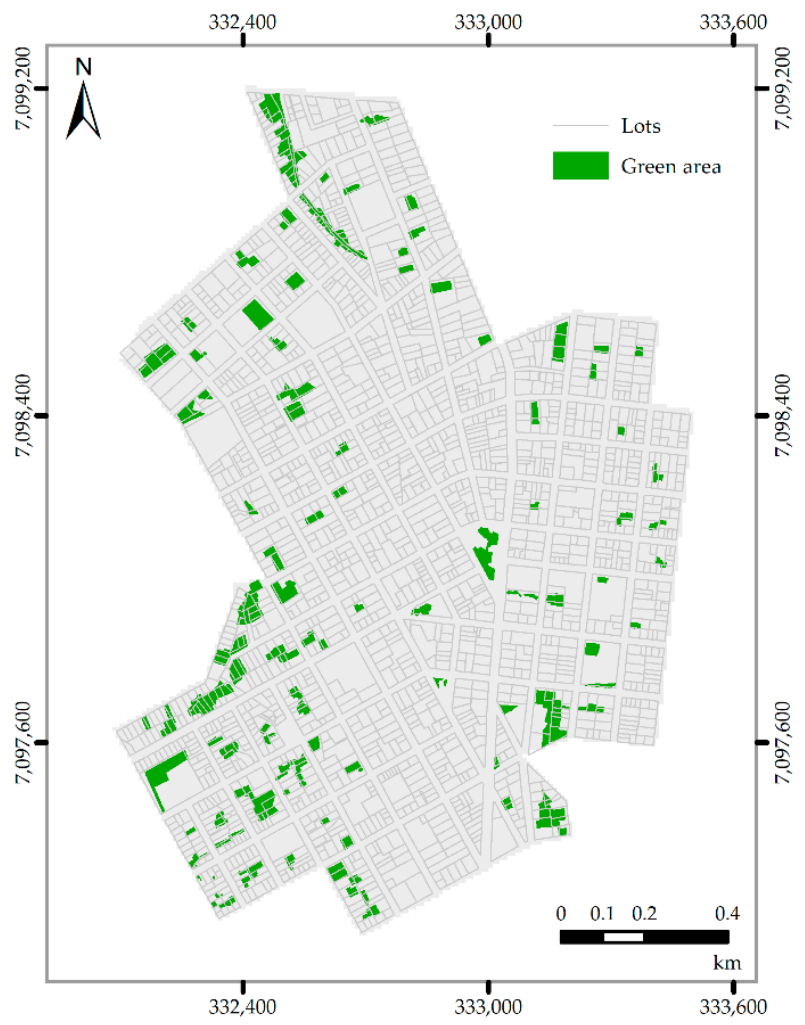

Figure 7. Areas identified to receive rain gardens.

Regarding green roofs, the criterion of the existence of buildings with flat slab coverage was considered. Due to flat slabs occurrences being higher in buildings with more than four floors, green roofs provide an alternative to mitigate floods in areas with a higher rate of vertical urbanization, as well as to contribute to the reduction of heat islands [67]. Thus, there is a predominance of single-story buildings or with less than four floors in the area, which would require major adaptations to receive a green roof.

For geomorphology (Figure 8), the study area has a rugged relief. The slope is characterized by the predominance of slopes between $0 \%$ and $20 \%$, with some regions reaching values close to $70 \%$. The slope level is classified as nearly slope $(<3 \%)$, gentle slope $(3 \%-5 \%)$, sloping slope $(5 \%-12 \%)$, moderate slope $(12 \%-20 \%)$, moderate steep slope $(20 \%-45 \%)$, and steep $(>45 \%)$.

We observed that the central area has a predominant slope of $0 \%$ to $5 \%$ (Figure 8 ). With consolidated urbanization, this area has the potential for retrofit, mainly with the transformation of paved areas into permeable pavements. Rain gardens also require land with slopes up to $12 \%$, however, the areas identified for its implementation are located mainly on the sides of the study area, which have a higher incidence of moderate to accentuated slopes.

Considering the slope of the site (Figure 8), it is visible that the favorable area for permeable pavements and rain gardens decreases from the area originally expected (Figures 9 and 10). This is explained by the imposed slope limitation ( $5 \%$ for permeable floors and $12 \%$ for rain gardens). In greater inclinations, the implementation of LID requires adaptations and studies of its own, which would demand a higher cost and may make its execution unfeasible.

Concerning the area destined for each LID, with the use of the soil as the main condition, it is noted that of the total study area $\left(1,857,630.05 \mathrm{~m}^{2}\right), 25.87 \%$ is available or fits the selection criteria (Table 2). After applying the conditions, the possibility of using permeable pavements and rain gardens decreases $(59.59 \%$ and $51.98 \%$, respectively), resulting in a total of $13.30 \%$ of the area. 


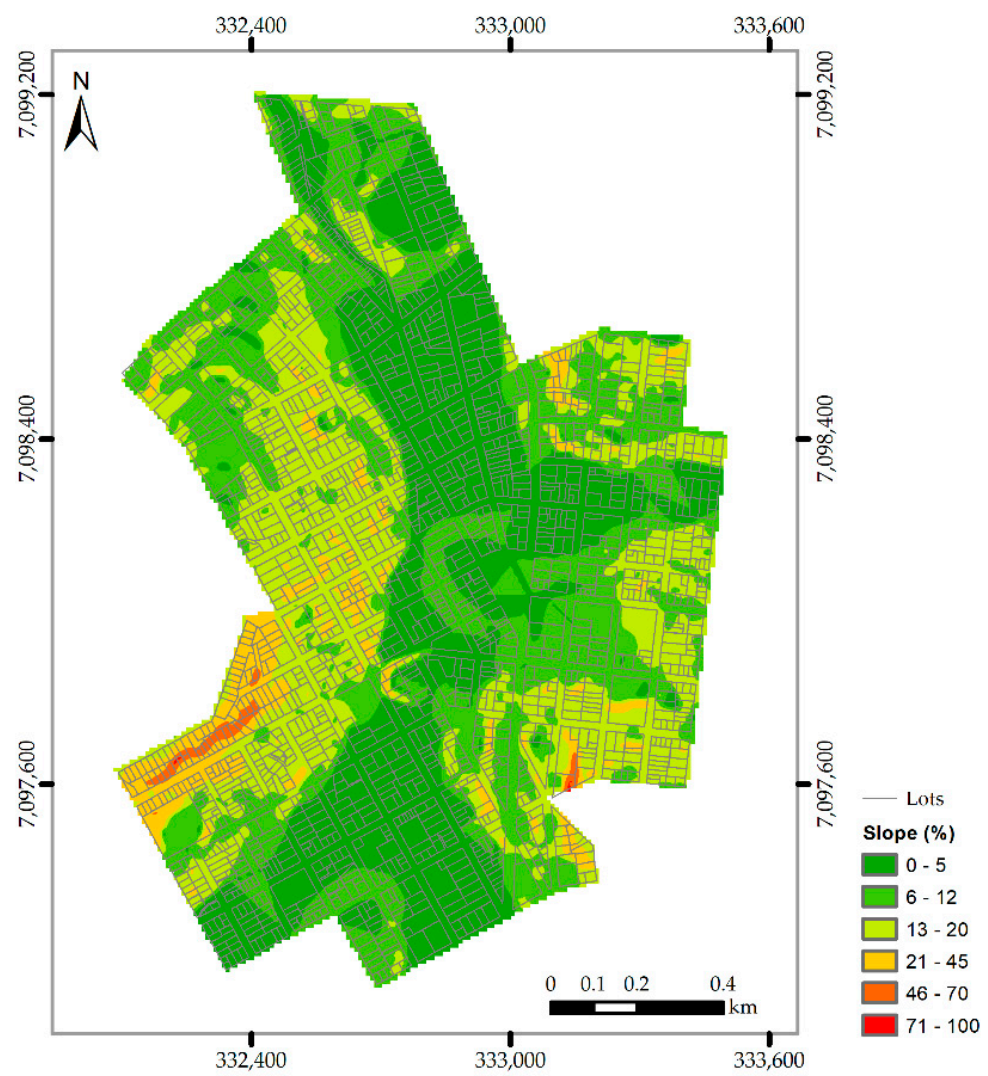

Figure 8. Slope map.

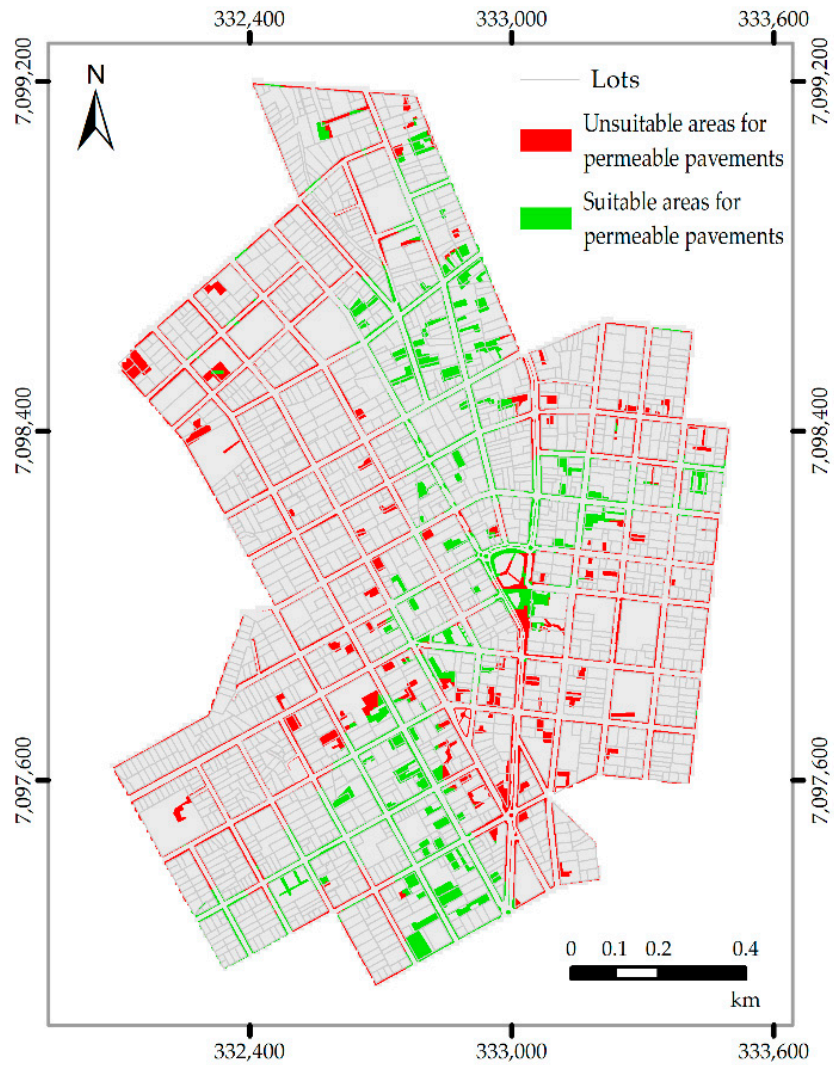

Figure 9. Suitable areas for the permeable pavement installation. 


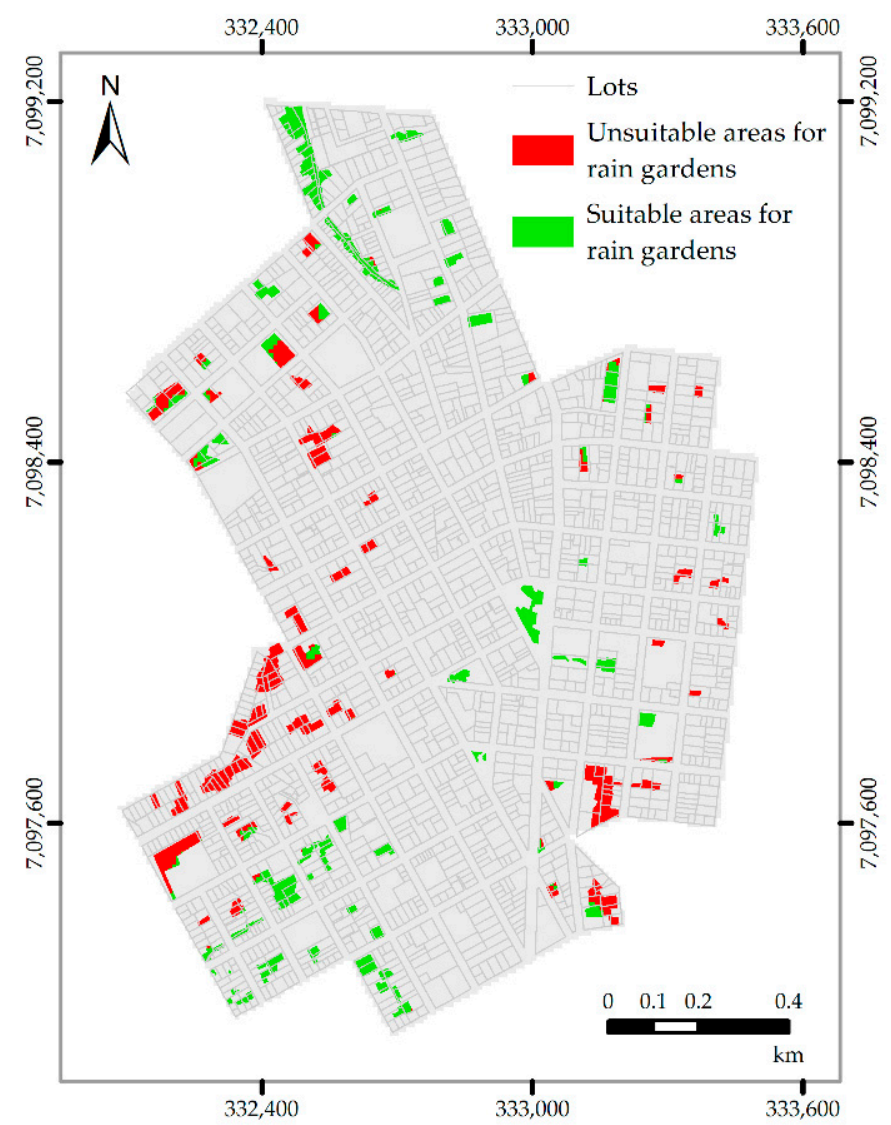

Figure 10. Suitable areas for the implantation of rain gardens.

Table 2. Dimensioning of areas suitable for the LID.

\begin{tabular}{ccccc}
\hline & $\begin{array}{c}\text { Initially Selected } \\
\text { Area } \mathbf{( m}^{\mathbf{2}} \mathbf{)}\end{array}$ & $\begin{array}{c}\text { Proportionality } \\
\text { of Total Area } \mathbf{( \% )}\end{array}$ & Suitable Area $\mathbf{( m}^{\mathbf{2}} \mathbf{)}$ & $\begin{array}{c}\text { Proportionality } \\
\text { of Total Area } \mathbf{( \% )}\end{array}$ \\
\hline Permeable pavement & $289,664.30$ & 15.59 & $116,980.68$ & 6.30 \\
Green roof & $73,773.00$ & 3.97 & $73,773.00$ & 3.97 \\
Rain garden & $117,273.02$ & 6.31 & $56,243.75$ & 3.03 \\
\hline Total & $480,710.32$ & 25.87 & $246,997.43$ & 13.30 \\
\hline
\end{tabular}

Thus, the results (Table 2) show that permeable pavements are recommended for $6.30 \%$ of the entire study area, green roofs can be implanted in $3.97 \%$ of the area and $3.03 \%$ of this can receive gardens of rain. In total, $13.30 \%$ of the central region of Pato Branco can receive LID.

As for rainwater harvesting, there are no restrictions on their use. In addition, a variation of tank sizes is possible, according to the demand or built area. For the analysis of the application of rainwater harvesting, a survey of the construction areas in the study area was carried out, where it was found that there are 1536 properties (Table 3).

Table 3. Dimensioning of areas suitable for rainwater harvesting.

\begin{tabular}{|c|c|c|c|c|}
\hline & $\begin{array}{l}\text { Buildings Smaller } \\
\text { than } 100 \mathrm{~m}^{2}\end{array}$ & $\begin{array}{l}\text { Buildings Larger than } 100 \mathrm{~m}^{2} \\
\text { and Smaller than } 300 \mathrm{~m}^{2}\end{array}$ & $\begin{array}{l}\text { Buildings Larger } \\
\text { than } 300 \mathrm{~m}^{2}\end{array}$ & Total \\
\hline Number of buildings & 135 & 654 & 747 & 1536 \\
\hline Tank capacity & $3 \mathrm{~m}^{3}$ & $5 \mathrm{~m}^{3}$ & $10 \mathrm{~m}^{3}$ & - \\
\hline Storage capacity & $405 \mathrm{~m}^{3}$ & $3270 \mathrm{~m}^{3}$ & $7470 \mathrm{~m}^{3}$ & $11,145 \mathrm{~m}^{3}$ \\
\hline
\end{tabular}


To evaluate its application, three tank sizes were defined according to the built area of each building. Thus, tanks of 3,5 , and $10 \mathrm{~m}^{3}$ will be associated with homes with less than $100 \mathrm{~m}^{2}$, from 100 to $300 \mathrm{~m}^{2}$ and above $300 \mathrm{~m}^{2}$, respectively. Thus, it was observed that the use of rainwater harvesting could store up to 11,145,000 L of rainwater. Steffen et al. [68], in their study, they observed that rainwater storage tanks have a high potential for saving drinking water, especially in regions with annual rainfall above $762 \mathrm{~mm}$. However, the main obstacles that may exist in the adoption of rainwater harvesting are the high capital costs, mainly in single-family houses, the maintenance costs in multi-family buildings, and the lack of knowledge of the system by the population [69].

Through the data obtained, it is noticeable that rainwater harvesting is a LID method that can be widely used due to the availability of locations. However, infiltration-based typologies, such as permeable pavements, have a better performance in reducing runoff [70].

Figure 11 shows a summary of all areas suitable for the application of LID. Observe a higher concentration of areas suitable for the implementation of green roofs and permeable pavements in regions with greater urbanization and soil drainage. The rain gardens are more notable in areas far from the central town. Besides, the central core area is characterized by slight inclination, which allows the implementation of systems that have the slope as a limiting factor.

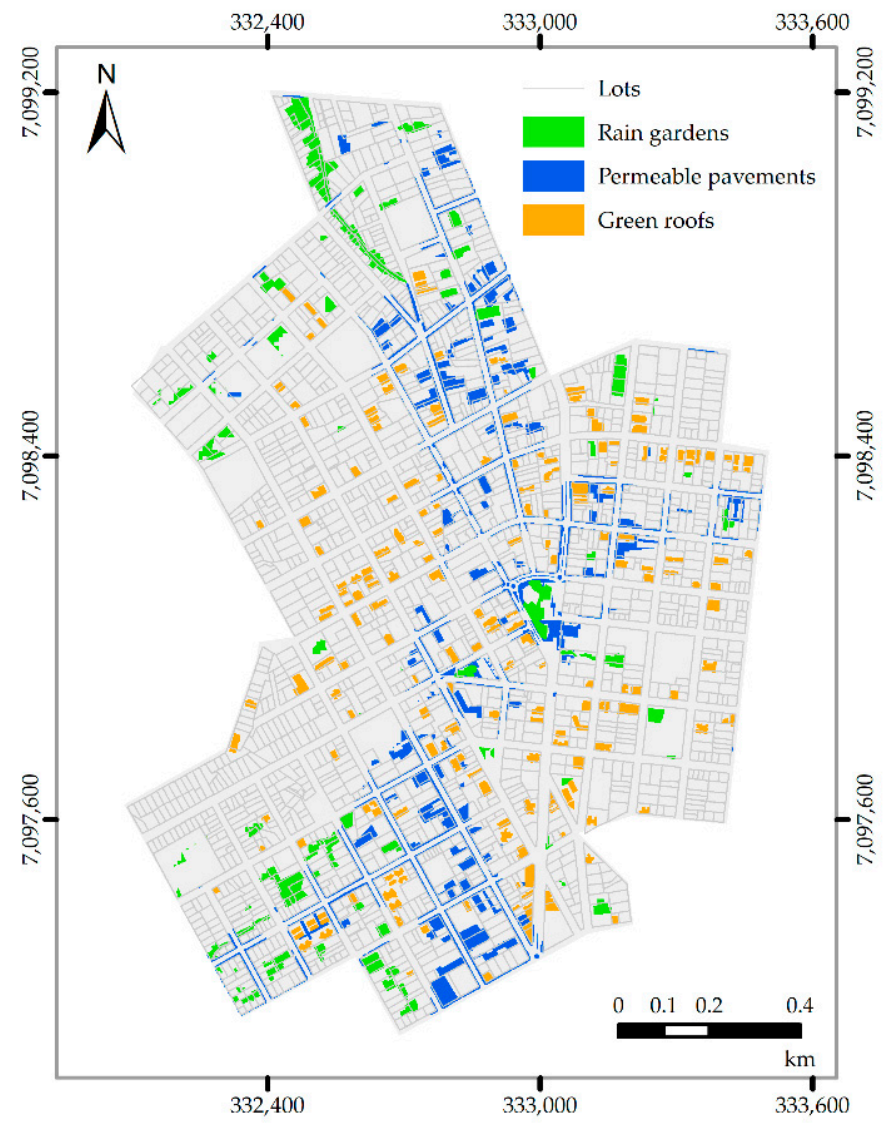

Figure 11. Areas indicated for the use of LID models.

Figure 12 shows the flood susceptibility map. As already mentioned, this map considers factors such as land use, rainfall, slope, and geology. Analyzing this map, note that the central region of the study area tends to receive the largest flow of runoff and, consequently, presents the highest risk of flooding. In fact, from population reports, floods occur annually in the high susceptibility area shown on the map. 


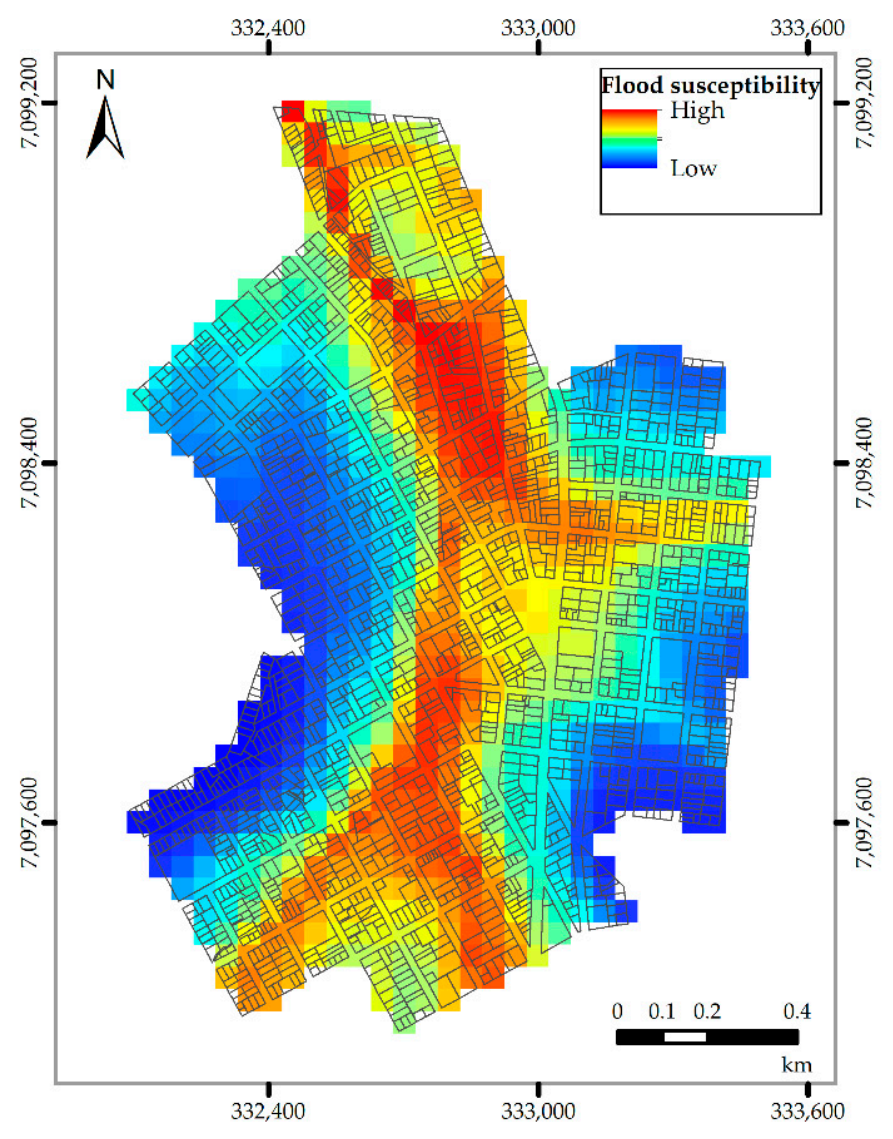

Figure 12. Flood susceptibility map.

Analyzing Figures 11 and 12 it is noticeable that the permeable pavement is one of the types of LIDs indicated for that region. Currently, this area does not have any type of LID that allows the permeability of the surface.

The GIS-based multicriteria analysis proved to be efficient at choosing locations with potential for LIDs installation. In this investigation, we have presented a method to identify areas that meet all the established requirements, which helps companies and government officials in the decision-making process.

Moreover, observe that for the use of LIDs in environments with consolidated urbanization should be considered the land use and the slope as factors for choosing the most appropriate models to the reality of the local. In this sense, the use of LIDs, combined with the conventional urban drainage systems that already exist, contributes to the natural water cycle in the urban environment.

In this study, no distinctions were made between public and private properties. One of the biggest problems related to the implantation of sustainable urban drainage systems is that, for its effectiveness, there is a dependence on the adhesion of private owners, which makes the development of legal instruments essential to enable the adoption of these practices. Another problem, mentioned by Baptista and Nascimento [71], is related to the search, by individuals, for the most economical solution to the detriment of the most ecological.

Although rainwater management is expensive, the costs of damage resulting from rainwater runoff can be even higher. The costs of rainwater damage, including damage from property flooding, degradation of water quality and loss of natural resources, reveal that the potential benefits outweigh the cost of rainwater management.

Urban drainage management and planning must start at the level of individual property, moving forward with linking these activities to the neighborhood level and, finally, scaling them up to the level of the hydrographic basin. Moreover, public education on the need for stormwater mitigation and 
the benefits of effective stormwater management can motivate the public and authorities to increase efforts and investments in stormwater programs [72,73]. The effective management of urban waters must also be attentive to the projected changes to the climate, as they should lead to an increase in temperatures, frequency, and intensity of extreme rain events [74].

In this context, the effective implementation of sustainable urban drainage systems must be a mutual effort between the population and urban planners. Thus, the knowledge of the retrofit techniques appropriate for each region, as well as the scale and to what extent they can be applied, helps managers and decision-makers to plan urban drainage systems sustainably and effectively. As for property owners, the adoption of sustainable techniques can cause, in addition to the aesthetic benefit, an increase in the economic value of the property.

\section{Conclusions}

Stimulated by the challenge of adapting cities to climate change, rainwater management is one of the priorities for sustainable development. In this sense, LIDs aim to restore the hydrological flow regime of urban areas, promoting infiltration, retention and evapotranspiration in the place. However, the effectiveness of LIDs is influenced not only by their design, but also by their location.

In a general context, the methodology used can identify areas with potential applications of LIDs to improve the management of rainwater. In this sense, the methods analyzed are alternatives for the management of urban drainage and, consequently, can minimize the impacts caused by the urbanization process and contributes to the natural water cycle in the urban environment.

Finally, we can conclude that the use of geoprocessing and multicriteria analysis tools are effective in the management of the urban territory. The proposed methodology assists individuals who may be interested in using one of the LIDs techniques in their homes, as well as companies and government agencies in aid decision-making and urban planning with a focus on sustainable urban drainage. Thus, the adoption of LID can bring numerous benefits, acting in an integrated manner with existing drainage structures. Even without the elimination of flood events, the adoption of sustainable drainage techniques contributes to the mildness of the climate, increased biodiversity, and the quality of the water that reaches the rivers.

The proposed model can be applied to other regions that are also susceptible to flooding, with adaptation to local characteristics and scenery. Besides, the model can be improved by adding criteria such as social and economic characteristics, which can be incorporated into the modeling proposed here. For practical use of the results, modeling and field studies must be considered to take into account all the complex watershed processes necessary to define the project specifications before implementation. In further investigations, the complexity of the model will be increased when an adaptive decision tree will be implemented, based on social, economic criteria, public facilities, and other dimensions that can impact the concept of the smart city.

Author Contributions: Conceptualization, C.R.d.A., J.K.N. and T.C.L.; methodology, J.K.N. and T.C.L.; formal analysis, C.R.d.A.; investigation, J.K.N. and T.C.L.; writing-original draft preparation, C.R.d.A., J.K.N. and T.C.L.; writing-review and editing, C.R.d.A.; supervision, C.R.d.A. All authors have read and agreed to the published version of the manuscript.

Funding: This research received no external funding.

Conflicts of Interest: The authors declare no conflict of interest.

\section{References}

1. Huang, J.; He, J.X.; Valeo, C.; Chu, A. Temporal evolution modeling of hydraulic and water quality performance of permeable pavements. J. Hydrol. 2016, 533, 15-27. [CrossRef]

2. Hou, J.M.; Zhang, Y.W.; Tong, Y.; Guo, K.H.; Qi, W.C.; Hinkelmann, R. Experimental study for effects of terrain features and rainfall intensity on infiltration rate of modelled permeable pavement. J. Environ. Manag. 2019, 243, 177-186. [CrossRef] 
3. Su, W.Z.; Duan, H.T. Catchment-based imperviousness metrics impacts on floods in Niushou River basin, Nanjing City, East China. Chin. Geogr. Sci. 2017, 27, 229-238. [CrossRef]

4. Talib, A.; Randhir, T.O. Climate change and land use impacts on hydrologic processes of watershed systems. J. Water Clim. Chang. 2017, 8, 363-374. [CrossRef]

5. Yin, J.B.; Gentine, P.; Zhou, S.; Sullivan, S.C.; Wang, R.; Zhang, Y.; Guo, S.L. Large increase in global storm runoff extremes driven by climate and anthropogenic changes. Nat. Commun. 2018, 9, 1034-1050. [CrossRef] [PubMed]

6. Wang, H.; Mei, C.; Liu, J.H.; Shao, W.W. A new strategy for integrated urban water management in China: Sponge city. Sci. China Technol. Sci. 2018, 61, 317-329. [CrossRef]

7. Erickson, T.; Stefan, H. Natural Groundwater Recharge Response to Urbanization: Vermillion River Watershed, Minnesota. J. Water Resour. Plan. Manag. 2009, 135, 512-520. [CrossRef]

8. Dilley, M.; Chen, R.S.; Deichmann, U.; Lerner-Lam, A.L.; Arnold, M. Natural disaster hotspots: A global risk analysis. World Bank 2005, 1, 145.

9. Kotzee, I.; Reyers, B. Piloting a social-ecological index for measuring flood resilience: A composite index approach. Ecol. Indic. 2016, 60, 45-53. [CrossRef]

10. Khajehei, S.; Ahmadalipour, A.; Shao, W.Y.; Moradkhani, H. A Place-based Assessment of Flash Flood Hazard and Vulnerability in the Contiguous United States. Sci. Rep. 2020, 10. [CrossRef]

11. Spitalar, M.; Gourley, J.J.; Lutoff, C.; Kirstetter, P.E.; Brilly, M.; Carr, N. Analysis of flash flood parameters and human impacts in the US from 2006 to 2012. J. Hydrol. 2014, 519, 863-870. [CrossRef]

12. Yu, H.F.; Zhao, Y.L.; Fu, Y.C.; Li, L. Spatiotemporal Variance Assessment of Urban Rainstorm Waterlogging Affected by Impervious Surface Expansion: A Case Study of Guangzhou, China. Sustainability 2018, 10, 3761. [CrossRef]

13. Aroca-Jiménez, E.; Bodoque, J.M.; Garcia, J.A.; Diez-Herrero, A. A quantitative methodology for the assessment of the regional economic vulnerability to flash floods. J. Hydrol. 2018, 565, 386-399. [CrossRef]

14. Arnell, N.W.; Gosling, S.N. The impacts of climate change on river flood risk at the global scale. Clim. Chang. 2016, 134, 387-401. [CrossRef]

15. Nikulin, G.; Kjellstrom, E.; Hansson, U.; Strandberg, G.; Ullerstig, A. Evaluation and future projections of temperature, precipitation and wind extremes over Europe in an ensemble of regional climate simulations. Tellus Ser. A Dyn. Meteorol. Oceanogr. 2011, 63, 41-55. [CrossRef]

16. IPCC. Climate Change 2014 Part A: Global and Sectoral Aspects; Cambridge University Press: Cambridge, UK, 2014.

17. Shehata, M.; Mizunaga, H. Flash Flood Risk Assessment for Kyushu Island, Japan. Environ. Earth Sci. 2018, 77. [CrossRef]

18. Creutin, J.D.; Borga, M. Radar hydrology modifies the monitoring of flash-flood hazard. Hydrol. Process. 2003, 17, 1453-1456. [CrossRef]

19. Mitchell, V.G. Applying integrated urban water management concepts: A review of Australian experience. Environ. Manag. 2006, 37, 589-605. [CrossRef]

20. Qiu, Y.; Ichiba, A.; Paz, I.S.R.; Chen, F.; Versini, P.A.; Schertzer, D.; Tchiguirinskaia, I. Evaluation of Low Impact Development and Nature-Based Solutions for stormwater management: A fully distributed modelling approach. Hydrol. Earth Syst. Sci. Discuss. 2019. [CrossRef]

21. Li, C.; Peng, C.; Chiang, P.; Cai, Y.; Wang, X.; Yang, Z. Mechanisms and Applications of Green Infrastructure Practices for Stormwater Control: A Review. J. Hydrol. 2018, 568, 626-637. [CrossRef]

22. Shuster, W.; Rhea, L. Catchment-scale hydrologic implications of parcel-level stormwater management (Ohio USA). J. Hydrol. 2013, 485, 177-187. [CrossRef]

23. Burns, M.J.; Fletcher, T.D.; Walsh, C.J.; Ladson, A.R.; Hatt, B.E. Hydrologic shortcomings of conventional urban stormwater management and opportunities for reform. Landsc. Urban Plan. 2012, 105, 230-240. [CrossRef]

24. Schueler, T.; Hirschman, D.; Novotney, M.; Zielinski, J. Urban Subwatershed Restoration Manual No. 3: Urban Stormwater Retrofit Practices; Center for Watershed Protection: Washington, DC, USA, 2007; Volume 3, 262p.

25. Hellmers, S.; Manojlovic, N.; Palmaricciotti, G.; Frohle, P. Modelling decentralised systems for urban drainage and flood mitigation. J. Appl. Water Eng. Res. 2017, 5, 61-69. [CrossRef]

26. Zhou, Q.Q. A review of sustainable urban drainage systems considering the climate change and urbanization impacts. Water 2014, 6, 976-992. [CrossRef]

27. Stovin, V.; Vesuviano, G.; Kasmin, H. The hydrological performance of a green roof test bed under UK climatic conditions. J. Hydrol. 2012, 414, 148-161. [CrossRef] 
28. Ahiablame, L.M.; Engel, B.A.; Chaubey, I. Effectiveness of low impact development practices: Literature review and suggestions for future research. Water Air Soil Pollut. 2012, 223, 4253-4273. [CrossRef]

29. Zhang, K.; Chui, T.F.M. A comprehensive review of spatial allocation of LID-BMP-GI practices: Strategies and optimization tools. Sci. Total Environ. 2018, 621, 915-929. [CrossRef]

30. Razzaghmanesh, M.; Borst, M. Monitoring the performance of urban green infrastructure using a tensiometer approach. Sci. Total Environ. 2019, 651, 2535-2545. [CrossRef]

31. Rodriguez-Rojas, M.I.; Huertas-Fernández, F.; Moreno, B.; Martínez, G.; Grindlay, A.L. A study of the application of permeable pavements as a sustainable technique for the mitigation of soil sealing in cities: A case study in the south of spain. J. Environ. Manag. 2018, 205, 151-162. [CrossRef]

32. Brown, R.A.; Borst, M. Quantifying evaporation in a permeable pavement system. Hydrol. Process. 2015, 29, 2100-2111. [CrossRef]

33. Beaupre, D.; Jencks, R.; Minick, S.; Mundy, J.; Navarret, A. Appendix A: BMP Fact Sheets. In San Francisco Stormwater Design Guidelines; San Francisco Public Utilities Commission: San Francisco, CA, USA, 2010; 120p.

34. Stander, E.K.; Rowe, A.A.; Borst, M.; O'Connor, T.P. Novel Use of Time Domain Reflectometry in Infiltration-Based Low Impact Development Practices. J. Irrig. Drain. Eng. 2013, 139, 625-634. [CrossRef]

35. Ávila, H.; Amaris, G.; Buelvas, J. Identifying Potential Areas for SUDS Application in Consolidated Urban Watersheds Based on GIS. In Water, Wastewater, and Stormwater and Urban Watershed Symposium; American Society of Civil Engineers: Reston, VA, USA, 2016; pp. 106-114.

36. Christman, Z.; Meenar, M.; Mandarano, L.; Hearing, K. Prioritizing Suitable Locations for Green Stormwater Infrastructure Based on Social Factors in Philadelphia. Land 2018, 7, 145. [CrossRef]

37. Carter, T.; Jackson, C.R. Vegetated roofs for stormwater management at multiple spatial scales. Landsc. Urban Plan. 2007, 80, 84-94. [CrossRef]

38. Ballard, B.W.; Wilson, S.; Udale-Clarke, H.; Illman, S.; Scott, T.; Ashley, R.; Kellagher, R. The SuDS Manual; CIRIA: London, UK, 2015; 940p, ISBN 978-0-86017-760-9.

39. Campisano, A.; Butler, D.; Ward, S.; Burns, M.J.; Friedler, E.; DeBusk, K.; Fisher-Jeffes, L.N.; Ghisi, E.; Rahman, A.; Furumai, H.; et al. Urban rainwater harvesting systems: Research, implementation and future perspectives. Water Res. 2017, 115, 195-209. [CrossRef] [PubMed]

40. Ristic, V.; Maksin, M.; Nenković-Riznić, M.; Basarić, J. Land-use evaluation for sustainable construction in a protected area: A case of Sara mountain national park Vladica Risti. J. Environ. Manag. 2018, 206, 430-445. [CrossRef]

41. Shariat, R.; Roozbahani, A.; Ebrahimin, A. Risk analysis of urban stormwater infrastructure systems using fuzzy spatial multi-criteria decision making. Sci. Total Environ. 2019, 647, 1468-1477. [CrossRef]

42. Inamdar, P.M.; Sharma, A.K.; Cook, S.; Perera, B.J.C. Evaluation of Stormwater Harvesting Sites Using Multi Criteria Decision Methodology. J. Hydrol. 2018, 562, 181-192. [CrossRef]

43. Ariza, S.L.J.; Martínez, J.A.; Muñoz, A.F.; Quijano, J.P.; Rodriguez, J.P.; Camacho, L.A.; Diaz-Granados, M. A Multicriteria Planning Framework to Locate and Select Sustainable Urban Drainage Systems (SUDS) in Consolidated Urban Areas. Sustainability 2019, 11, 2312. [CrossRef]

44. Ahiablame, L.M.; Engel, B.A.; Chaubey, I. Effectiveness of low impact development practices in two urbanized watersheds: Retrofitting with rain barrel/cistern and porous pavement. J. Environ. Manag. 2013, 119, 151-161. [CrossRef]

45. Wright, T.J.; Liu, Y.; Carroll, N.J.; Ahiablame, L.M.; Engel, B.A. Retrofitting LID practices into existing neighborhoods: Is it worth it? Environ. Manag. 2016, 57, 856-867. [CrossRef]

46. Hu, M.; Zhang, X.; Li, Y.; Yang, H.; Tanaka, K. Flood mitigation performance of low impact development technologies under different storms for retrofitting an urbanized area. J. Clean. Prod. 2019, 222, 373-380. [CrossRef]

47. Guo, X.; Du, P.; Zhao, D.; Li, M. Modelling low impact development in watersheds using the storm water management model. Urban Water J. 2019, 16, 146-155. [CrossRef]

48. Qin, H.; Li, Z.; Fu, G. The effects of low impact development on urban flooding under different rainfall characteristics. J. Environ. Manag. 2013, 129, 577-585. [CrossRef] [PubMed]

49. Eckart, K.; Mcphee, Z.; Bolisetti, T. Performance and implementation of low impact development-A review. Sci. Total Environ. 2017, 607, 413-432. [CrossRef] [PubMed]

50. IBGE. Censo Demográfico. 2020. Available online: www.ibge.gov.br (accessed on 6 August 2020). 
51. Hutchinson, M.F. A new procedure for gridding elevation and streamline data with automatic removal of spurious pits. J. Hydrol. 1989, 106, 211-232. [CrossRef]

52. Curebal, I.; Efe, R.; Ozdemir, H.; Soykan, A.; Sönmez, S. GIS-based approach for flood analysis: Case study of Keçidere flash flood event (Turkey). Geocarto Int. 2016, 31, 355-366. [CrossRef]

53. Salekin, S.; Burgess, J.H.; Morgenroth, J.; Mason, E.G.; Meason, D.F. A Comparative Study of Three Non-Geostatistical Methods for Optimising Digital Elevation Model Interpolation. ISPRS Int. J. Geo-Inf. 2018, 7, 300. [CrossRef]

54. Burrough, P.A.; McDonell, R.A.; Lloyd, C.D. Principles of Geographical Information Systems; Oxford University Press: Oxford, UK, 1998; 352p, ISSN 1567-5777.

55. Department of Environemental Services. Storm Water Best Management Practice Manual; City and County of Honolulu: Kapolei, HI, USA, 2012.

56. Los Angeles. Planning and Land Development Handbook for Low Impact Development (LID); City of Los Angeles: Los Angeles, CA, USA, 2016; Volume 5, 55p.

57. PSP. Low Impact Development Technical Guidance Manual; Washington State University: Pullman, WA, USA, 2012; p. 346.

58. Luo, X.Q.; Zhang, Z.C.; Wu, X.J. A novel algorithm of remote sensing image fusion based on shift-invariant Shearlet transform and regional selection. Int. J. Electron. Commun. 2016, 70, 186-197. [CrossRef]

59. Zadeh, L.A. Fussy sets. Inf. Control 1965, 8, 338-353. [CrossRef]

60. Asakereh, A.; Soleymani, M.; Sheikhdavoodi, M.J. A GIS-based Fuzzy-AHP method for the evaluation of solar farms locations: Case study in Khuzestan province, Iran. Sol. Energy 2017, 155, 342-353. [CrossRef]

61. Chang, N.B.; Parvathinathan, G.; Breeden, J.B. Combining GIS with fuzzy multicriteria decision-making for landfill siting in a fast-growing urban region. J. Environ. Manag. 2008, 87, 139-153. [CrossRef] [PubMed]

62. Ou, G.L.; Tan, S.K.; Zhou, M.; Lu, S.S.; Tao, Y.H.; Zhang, Z.; Zhang, L.; Yan, D.P.; Guan, X.L.; Wu, G. An interval chance-constrained fuzzy modeling approach for supporting land-use planning and eco-environment planning at a watershed level. J. Environ. Manag. 2017, 204, 651-666. [CrossRef] [PubMed]

63. Saaty, R.W. The analytic hierarchy process-what it is and how it is used. Math. Model. 1987, 9, 161-176. [CrossRef]

64. Biluca, J.; Aguiar, C.R.; Trojan, F. Sorting of suitable areas for disposal of construction and demolition waste using GIS and ELECTRE TRI. Waste Manag. 2020, 114, 307-320. [CrossRef]

65. Melville-Shreeve, P.; Cotterill, S.; Grant, L.; Arahuetes, A.; Stovin, V.; Farmani, R.; Butler, D. State of SuDS delivery in the United Kingdom. Water Environ. J. 2018, 32, 9-16. [CrossRef]

66. Jato-Espino, D.; Sillanpää, N.; Charlesworth, S.M.; Andrés-Doménech, I. Coupling GIS with Stormwater Modelling for the Location Prioritization and Hydrological Simulation of Permeable Pavements in Urban Catchments. Water 2016, 8, 451. [CrossRef]

67. Hager, J.; Hu, G.H.; Hewage, K.; Sadiq, R. Performance of low-impact development best management practices: A critical review. Environ. Rev. 2019, 27, 17-42. [CrossRef]

68. Steffen, J.; Jensen, M.; Pomeroy, C.A.; Burian, S.J. Water supply and stormwater management benefits of residential rainwater harvesting in U.S. cities. J. Am. Water Resour. Assoc. 2013, 49, 810-824. [CrossRef]

69. Domènech, L.; Saurí, D. A comparative appraisal of the use of rainwater harvesting in single and multifamily buildings of the Metropolitan Area of Barcelona (Spain): Social experience, drinking water savings and economic costs. J. Clean. Prod. 2011, 19, 598-608. [CrossRef]

70. Abi Aad, M.P.; Suidan, M.T.; Shuster, W.D. Modeling Techniques of Best Management Practices: Rain Barrels and Rain Gardens Using EPA SWMM-5. J. Hydrol. Eng. 2009, 15. [CrossRef]

71. Baptista, M.B.; Nascimento, N.O. Aspectos Institucionais e de Financiamento dos Sistemas de Drenagem Urbana. Revista Brasileira de Recursos Hídricos 2016, 7, 29-49. [CrossRef]

72. Visitacion, B.V.; Booth, D.B.; Steinemann, A.C. Costs and benefits of storm-water management: Case study of the Puget Sound Region. J. Urban Plan. Dev. 2009, 135, 150-158. [CrossRef]

73. Marsalek, J.; Schereier, H. Innovation in stormwater management in Canada: The way forward. Water Qual. Res. J. Can. 2009, 44. [CrossRef]

74. Trenberth, K.E. Changes in precipitation with climate change. Clim. Res. 2011, 47, 123-138. [CrossRef]

(C) 2020 by the authors. Licensee MDPI, Basel, Switzerland. This article is an open access article distributed under the terms and conditions of the Creative Commons Attribution (CC BY) license (http://creativecommons.org/licenses/by/4.0/). 